\title{
Systematic Review of Diagnostic Utility and Therapeutic Effectiveness of Thoracic Facet Joint Interventions
}

Sairam Atluri, MD¹, Sukdeb Datta, MD², Frank JE Falco, $\mathrm{MD}^{3}$, and Marion Lee, $\mathrm{MD}^{4}$

From: ${ }^{2}$ Tri-State Spine Care Institute, Cincinnati, $\mathrm{OH} ;{ }^{2}$ Vanderbilt University Medical Center, Nashville, TN; ${ }^{3}$ Mid Atlantic Spine \& Pain Specialists, Newark, DE; and

4The Pain Center at Affinity Health Group

Tifton, GA

Dr. Atluri, is Medical Director of the Tri-State Spine Care Institute, Cincinnati, $\mathrm{OH}$. Dr.

Datta is Director, Vanderbilt University Interventional Pain Program, Associate Professor, Dept. of Anesthesiology, Vanderbilt University Medical Center, Nashville, TN. Dr.

Falco is Medical Director of the Mid Atlantic Spine \& Pain Specialists of Newark, DE, and

Clinical Assistant Professor,

Temple University Medical

School, Philadelphia, PA. Dr.

Lee is Director of The Pain Center at Affinity Health Group, Tifton, GA.

Address correspondence: Sairam Atluri, MD Medical Director, Tri-State Spine Care Institute 7655 Five Mile Road, Suite 117 Cincinnati, OH 45230

E-mail: saiatluri@gmail.com

Disclaimer: There was no external funding in the preparation of this manuscript.

Conflict of interest: None.

Manuscript received: 08/08/2008

Revised manuscript received: 08/28/2008

Accepted for publication: 09/04/2008

Free full manuscript: www.painphysicianjournal.com
Background: Chronic mid back and upper back pain caused by thoracic facet joints has been reported in $34 \%$ to $48 \%$ of the patients based on the responses to controlled diagnostic blocks. Systematic reviews have established moderate evidence for controlled comparative local anesthetic blocks of thoracic facet joints in the diagnosis of mid back and upper back pain, moderate evidence for therapeutic thoracic medial branch blocks, and limited evidence for radiofrequency neurotomy of therapeutic facet joint nerves

Objectives: To determine the clinical utility of diagnostic and therapeutic thoracic facet joint interventions in diagnosing and managing chronic upper back and mid back pain.

Study Design: Systematic review of diagnostic and therapeutic thoracic facet joint interventions.

Methods: Review of the literature for utility of facet joint interventions in diagnosing and managing facet joint pain was performed according to the Agency for Healthcare Research and Quality (AHRQ) criteria for diagnostic studies and observational studies and the Cochrane Musculoskeletal Review Group criteria as utilized for interventional techniques for randomized trials. The level of evidence was classified as Level I, II, or III based on the quality of evidence developed by United States Preventive Services Task Force (USPSTF) for therapeutic interventions. Recommendations were based on the criteria developed by Guyatt et al.

Data sources included relevant literature of the English language identified through searches of Medline and EMBASE from 1966 to July 2008 and manual searches of bibliographies of known primary and review articles. Results of the analysis were performed for diagnostic and therapeutic interventions separately.

Outcome Measures: For diagnostic interventions, studies must have been performed utilizing controlled local anesthetic blocks. For therapeutic interventions, the primary outcome measure was pain relief (short-term relief $=$ up to 6 months and long-term relief $>6$ months) with secondary outcome measures of improvement in functional status, psychological status, return to work, and reduction in opioid intake.

Results: Based on the controlled comparative local anesthetic blocks, the evidence for the diagnosis of thoracic facet joint pain is Level I or II-1.

The evidence for therapeutic thoracic medial branch blocks is Level I or II-1. The recommendation is IA or $1 \mathrm{~B} /$ strong for diagnostic and therapeutic medial branch blocks.

Conclusion: The evidence for the diagnosis of thoracic facet joint pain with controlled comparative local anesthetic blocks is Level I or II-1.

The evidence for therapeutic facet joint interventions is Level I or II-1 for medial branch blocks.

Recommendation is $1 \mathrm{~A}$ or $1 \mathrm{~B} /$ strong for diagnostic and therapeutic medial branch blocks.

Key words: Chronic thoracic pain, mid back or upper back pain, thoracic facet or zygapophysial joint pain, facet joint nerve blocks, medial branch blocks, controlled comparative local anesthetic blocks, therapeutic thoracic medial branch blocks, thoracic radiofrequency neurotomy, thoracic intraarticular facet joint injections

Pain Physician 2008; 11:5:611-629 
A mong chronic pain disorders, pain arising from various structures of the spine constitutes the majority of problems. The lifetime prevalence of spinal pain has been reported as $54 \%$ to $80 \%$. However, the proportion of patients suffering from chronic upper or mid back pain secondary to thoracic disorders is relatively small, specifically in interventional pain management settings, ranging from $3 \%$ to $22 \%$ (1-3). Linton et al (4) estimated the prevalence of thoracic pain in $15 \%$ of the general population in contrast to $56 \%$ in the low back and $44 \%$ in the neck. Even though, the role of thoracic facet joints as a cause of chronic upper or mid back pain has received very little attention with only a few publications discussing these joints as the source of pain (1-3), the description of involvement of thoracic facet joints as a cause of chronic mid back and upper back pain dates back to 1987 (5). Thoracic facet joint pain patterns were described in 1994 and 1997 by Dreyfuss et al (6) and Fukui et al (7). Subsequently, studies utilizing controlled comparative local anesthetic blocks have been conducted (8-10). Thoracic facet joints have been implicated as the source of chronic pain in $34 \%$ to $48 \%$ of patients with chronic mid back and upper back pain (8-14).

Even though chronic spinal pain is considered as a multifactorial disorder with many possible etiologies, Bogduk (15) postulated that, for any structure to be deemed a cause of back pain, the structure should:

1) Have a nerve supply.

2) Be capable of causing pain of that similar to that seen clinically, ideally demonstrated in normal volunteers.

3) Be susceptible to diseases or injuries that are known to be painful.

4) Have been shown to be a source of pain in patients, using diagnostic techniques of known reliability and validity.

Consequently, based on these postulates, thoracic facet joints have been shown to have abundant nerve supply $(6,7,12,16-23)$; shown to be capable of causing pain similar to that seen clinically, in normal volunteers with persistent mid back and upper back pain and referred pain into the chest wall $(6,7)$; been shown to be affected by osteoarthritis, rheumatoid arthritis, spondylitis, degeneration, inflammation, and injury leading to pain upon joint motion and restriction of motion $(24,25)$; and to be a source of pain in patients, using diagnostic techniques of known re- liability and validity (8-10).

Medial branch blocks and radiofrequency neurotomy have been described in managing chronic mid back and upper back pain from thoracic facet joints (3,26-30). However, the evidence has been highly variable.

Systematic reviews have provided moderate evidence for thoracic medial branch diagnostic blocks (11-13) and for therapeutic thoracic medial branch blocks (27), whereas evidence for radiofrequency neurotomy of thoracic facet joint nerves was indeterminate $(27,28)$.

Conventional clinical and radiologic techniques used to diagnose appendicular joint pain are unreliable in diagnosing facet or zygapophysial joint pain $(11-15,23,26,27)$. Consequently, controlled local anesthetic blocks of thoracic facet joints or medial branch blocks are employed to diagnose facet joint pain. The rationale is that anesthetic blockade of a painful joint will abolish pain arising from the joint for the duration of the anesthetic effect, while anesthetic blockade of a non-painful joint will not alter the pain report. The probability that the blocked joint is the actual source of pain is increased if repeating the block with an anesthetic agent that has a different duration of action reproduces the analgesic response (11-15). To ensure accuracy and validity, these blocks must be controlled and verified for delivery of a local anesthetic agent and placebo response. Either placebo controlled or comparative local anesthetic blocks are employed to eliminate placebo responses. Single facet joint injections are not recommended, as they do not control for a false-positive response.

This systematic review is undertaken to determine the accuracy of thoracic facet joint blocks in the diagnosis and effectiveness of thoracic facet joint interventions in the management of chronic mid back and upper back pain.

\section{Methods}

\section{Literature Search}

A comprehensive literature search was conducted which included search of databases including Medline and EMBASE from 1966 through July 2008, Cochrane database, Clinical Trial Registry, systematic reviews, narrative reviews, cross-references to the reviews, and peer-reviewed abstracts from scientific meetings (during the past 2 years), published in the English language. 
The search strategy emphasized chronic thoracic pain of facet joint origin with a focus on all types of diagnostic and therapeutic interventions. Search terminology included thoracic facet joint, thoracic facet joint pain, thoracic diagnostic facet joint blocks, thoracic facet joint intraarticular injections, medial branch blocks, and radiofrequency neurotomy.

\section{Diagnostic Facet Joint Interventions}

\section{Inclusion Criteria}

Prospective and retrospective studies published on the diagnosis of thoracic facet joint pain in patients with chronic pain of greater than 3 months duration were included for review. Only the studies utilizing controlled diagnostic blocks under fluoroscopy were included. The criterion standard for diagnosis of thoracic facet joint pain was at least greater than $50 \%$ pain relief for the duration of local anesthetic and ability to perform previously painful movements.

\section{Exclusion Criteria}

All non-clinical studies were excluded. Further, ultrasound guided injections, case reports, book chapters, non-evidence-based guidelines, letters, and expert opinions were excluded.

\section{Methodologic Quality Assessment}

Initially, all the abstracts obtained from computerized database searches were screened for inclusion/exclusion criteria. Two physician reviewers evaluated and graded articles meeting inclusion criteria for methodologic quality and grading of evidence as described by the Agency for Healthcare Research and Quality (AHRQ) for diagnostic studies as illustrated in Table 1 (31).

The quality of individual articles was evaluated using the above criteria with application of consensus based weighted scores developed by the guidelines committee of the American Society of Interventional Pain Physicians (32).

Table 1. Modified AHRQ methodologic assessment criteria for diagnostic interventions.

\begin{tabular}{|c|c|}
\hline CRITERION & Weighted Score \\
\hline 1. Study Population & 30 \\
\hline \multicolumn{2}{|c|}{ - Subjects similar to populations in which the test would be used and with a similar spectrum of disease } \\
\hline 2. Adequate Description of Test & 15 \\
\hline \multicolumn{2}{|l|}{ - Details of test and its administration sufficient to allow for replication of study } \\
\hline 3. Appropriate Reference Standard & 20 \\
\hline - Appropriate reference standard (gold standard) used for comparison & 10 \\
\hline - Reference standard reproducible & 10 \\
\hline 4. Blinded Comparison of Test & 20 \\
\hline - Evaluation of test without knowledge of disease status, if possible & 10 \\
\hline - Independent, blind interpretation of test and reference & 10 \\
\hline 5. Avoidance of Verification Bias & 15 \\
\hline \multicolumn{2}{|c|}{ - Decision to perform reference standard not dependent on results of test under study } \\
\hline TOTAL SCORE & 100 \\
\hline
\end{tabular}

Adapted and modified from West S et al. Systems to Rate the Strength of Scientific Evidence, Evidence Report, Technology Assessment No. 47. AHRQ Publication No. 02-E016 (31). 
Table 2. Modified quality of evidence developed by USPSTF.

\begin{tabular}{|l|l||}
\hline \hline I: & Evidence obtained from at least one properly randomized controlled trial or multiple well-conducted diagnostic studies \\
\hline II-1: & $\begin{array}{l}\text { Evidence obtained from well-designed controlled trials without randomization or at least one well-controlled diagnostic study of } \\
\text { adequate size }\end{array}$ \\
\hline II-2: & $\begin{array}{l}\text { Evidence obtained from well-designed cohort or case-control analytic studies, preferably from more than one center or research } \\
\text { group or evidence obtained from at least one properly designed small diagnostic accuracy study }\end{array}$ \\
\hline II-3: & $\begin{array}{l}\text { Evidence obtained from multiple time series with or without the intervention. Dramatic results in uncontrolled experiments (such } \\
\text { as the results of the introduction of penicillin treatment in the 1940s) could also be regarded as this type of evidence }\end{array}$ \\
\hline III: & Opinions of respected authorities, based on clinical experience descriptive studies and case reports or reports of expert committees \\
\hline
\end{tabular}

Adapted from the U.S. Preventive Services Task Force (USPSTF) (33).

Table 3. Grading recommendations of Guyatt et al (34).

\begin{tabular}{|c|c|c|c|}
\hline $\begin{array}{c}\text { Grade of Recommendation/ } \\
\text { Description }\end{array}$ & $\begin{array}{c}\text { Benefit vs Risk and } \\
\text { Burdens }\end{array}$ & $\begin{array}{l}\text { Methodological Quality of } \\
\text { Supporting Evidence }\end{array}$ & Implications \\
\hline $\begin{array}{l}1 \mathrm{~A} / \text { strong recommendation, } \\
\text { high-quality evidence }\end{array}$ & $\begin{array}{l}\text { Benefits clearly outweigh } \\
\text { risk and burdens, or vice } \\
\text { versa }\end{array}$ & $\begin{array}{l}\text { RCTs without important limitations } \\
\text { or overwhelming evidence from } \\
\text { observational studies }\end{array}$ & $\begin{array}{l}\text { Strong recommendation, can } \\
\text { apply to most patients in most } \\
\text { circumstances without reservation }\end{array}$ \\
\hline $\begin{array}{l}1 \mathrm{~B} / \text { strong recommendation, } \\
\text { moderate quality evidence }\end{array}$ & $\begin{array}{l}\text { Benefits clearly outweigh } \\
\text { risk and burdens, or vice } \\
\text { versa }\end{array}$ & $\begin{array}{l}\text { RCTs with important limitations } \\
\text { (inconsistent results, methodological } \\
\text { flaws, indirect, or imprecise) or } \\
\text { exceptionally strong evidence from } \\
\text { observational studies }\end{array}$ & $\begin{array}{l}\text { Strong recommendation, can } \\
\text { apply to most patients in most } \\
\text { circumstances without reservation }\end{array}$ \\
\hline $\begin{array}{l}1 \mathrm{C} / \text { strong recommendation, } \\
\text { low-quality or very low-quality } \\
\text { evidence }\end{array}$ & $\begin{array}{l}\text { Benefits clearly outweigh } \\
\text { risk and burdens, or vice } \\
\text { versa }\end{array}$ & Observational studies or case series & $\begin{array}{l}\text { Strong recommendation but } \\
\text { may change when higher quality } \\
\text { evidence becomes available }\end{array}$ \\
\hline $\begin{array}{l}2 \mathrm{~A} / \text { weak recommendation, high- } \\
\text { quality evidence }\end{array}$ & $\begin{array}{l}\text { Benefits closely balanced } \\
\text { with risks and burden }\end{array}$ & $\begin{array}{l}\text { RCTs without important limitations } \\
\text { or overwhelming evidence from } \\
\text { observational studies }\end{array}$ & $\begin{array}{l}\text { Weak recommendation, best } \\
\text { action may differ depending on } \\
\text { circumstances or patients' or } \\
\text { societal values }\end{array}$ \\
\hline $\begin{array}{l}\text { 2B/weak recommendation, } \\
\text { moderate-quality evidence }\end{array}$ & $\begin{array}{l}\text { Benefits closely balanced } \\
\text { with risks and burden }\end{array}$ & $\begin{array}{l}\text { RCTs with important limitations } \\
\text { (inconsistent results, methodological } \\
\text { flaws, indirect, or imprecise) or } \\
\text { exceptionally strong evidence from } \\
\text { observational studies }\end{array}$ & $\begin{array}{l}\text { Weak recommendation, best } \\
\text { action may differ depending on } \\
\text { circumstances or patients' or } \\
\text { societal values }\end{array}$ \\
\hline $\begin{array}{l}2 \mathrm{C} / \text { weak recommendation, } \\
\text { low-quality or very low-quality } \\
\text { evidence }\end{array}$ & $\begin{array}{l}\text { Uncertainty in the estimates } \\
\text { of benefits, risks, and burden; } \\
\text { benefits, risk, and burden } \\
\text { may be closely balanced }\end{array}$ & Observational studies or case series & $\begin{array}{l}\text { Very weak recommendations; } \\
\text { other alternatives may be equally } \\
\text { reasonable }\end{array}$ \\
\hline
\end{tabular}

Adapted from Guyatt $\mathrm{G}$ et al. Grading strength of recommendations and quality of evidence in clinical guidelines. Report from an American College of Chest Physicians task force. Chest 2006; 129:174-181 (34).

\section{Analysis of Level of Evidence}

There is no hierarchy of evidence described for diagnostic studies grading and quality assessment as for therapeutic interventions. Thus, since proper diagnostic interventions are always non-randomized, modified quality of evidence developed by USPSTF, as illustrated in Table 2, was utilized (33).
Grading recommendations were provided based on Guyatt et al's (34) criteria which provided grade of recommendation based on benefit versus risk and burdens and methodological quality of supporting evidence from strong to weak with 3 subcategories in each category (Table 3 ).

Only the studies scoring at least 50 of 100 
on weighted scoring criteria were utilized for analysis.

Each study was evaluated by 2 physicians for stated criteria and any disagreements were resolved by the third physician.

\section{Therapeutic Facet Joint Interventions}

\section{Inclusion Criteria}

Studies should have documented the existence of thoracic spinal pain of facet joint origin using controlled diagnostic facet joint or nerve blocks. Three types of facet joint interventions were included in this review: intraarticular facet joint injections, medial branch blocks, and medial branch radiofrequency neurotomy. All studies must have provided appropriate management with outcome evaluations of at least 6 months and appropriate statistical analysis.

\section{Exclusion Criteria}

Reports without appropriate diagnosis and elimination of false-positive responses, abstracts beyond 2 years, non-systematic reviews, book chapters, and case reports were excluded.

\section{Outcome Parameters}

The primary outcome measure was pain relief at various time points reported at least over a period of 6 months. The secondary outcome measures were functional status improvement, psychological status improvement, return to work, and complications. Short-term pain relief was defined as relief lasting 6 months or less and long-term relief as longer than 6 months.

\section{Methodologic Quality Assessment}

The quality of each individual article used in this analysis was assessed by modified Cochrane review criteria with weighted scores (Table 4) (35) for randomized trials and AHRQ quality criteria for assessment of observational studies for non-randomized trials (Table 5) (31) with consensus-based weighted scoring developed by the guidelines committee of the American Society of Interventional Pain Physicians (32).

Only the studies scoring at least 50 of 100 on weighted scoring criteria were utilized for analysis.

Each study was evaluated by 2 physicians for stated criteria and any disagreements were resolved by the third physician.
Table 4. Modified and weighted Cochrane methodologic quality assessment criteria as described by Koes et al (35).

\begin{tabular}{|c|c|c|}
\hline & CRITERION & $\begin{array}{l}\text { Weighted } \\
\text { Score }\end{array}$ \\
\hline & population & 35 \\
\hline A & Homogeneity & 2 \\
\hline B & $\begin{array}{l}\text { Comparability of relevant baseline } \\
\text { characteristics }\end{array}$ & 5 \\
\hline $\mathrm{C}$ & Randomization procedure adequate & 4 \\
\hline $\mathrm{D}$ & $\begin{array}{l}\text { Drop-outs described for each study group } \\
\text { separately }\end{array}$ & 3 \\
\hline $\mathrm{E}$ & $<20 \%$ loss for follow-up & 2 \\
\hline & $<10 \%$ loss for follow-up & 2 \\
\hline $\mathrm{F}$ & $>50$ subject in the smallest group & 8 \\
\hline & $>100$ subjects in the smallest group & 9 \\
\hline & entions & 25 \\
\hline G & $\begin{array}{l}\text { Interventions included in protocol and } \\
\text { described }\end{array}$ & 10 \\
\hline $\mathrm{H}$ & Pragmatic study & 5 \\
\hline I & Co-interventions avoided & 5 \\
\hline $\mathrm{J}$ & Placebo-controlled & 5 \\
\hline & & 30 \\
\hline K & Patients blinded & 5 \\
\hline $\mathrm{L}$ & Outcome measures relevant & 10 \\
\hline M & Blinded outcome assessments & 10 \\
\hline $\mathrm{N}$ & Follow-up period adequate & 5 \\
\hline & presentation and analysis & 10 \\
\hline $\mathrm{O}$ & Intention-to-treat analysis & 5 \\
\hline $\mathrm{P}$ & $\begin{array}{l}\text { Frequencies of most important outcomes } \\
\text { presented for each treatment group }\end{array}$ & 5 \\
\hline & CORE & 100 \\
\hline
\end{tabular}

Adapted from Koes BW et al. Efficacy of epidural steroid injections for low-back pain and sciatica: A systematic review of randomized clinical trials. Pain 1995; 63:279-288 (35).

\section{Analysis of Evidence}

Qualitative analysis was conducted using 5 levels of evidence, ranging from Level I to Level III with subcategories in Level II, which defines short-term and long-term relief as illustrated in Table 2 (33).

Grading recommendations were based on Guyatt et al's (34) recommendations as illustrated in Table 3. 
Table 5. Modified AHRQ quality assessment criteria for observational studies.

\begin{tabular}{|c|c|}
\hline CRITERION & Weighted Score \\
\hline 1. Study Question & 2 \\
\hline \multicolumn{2}{|l|}{ - Clearly focused and appropriate question } \\
\hline 2. Study Population & 8 \\
\hline - Description of study population & 5 \\
\hline - Sample size justification & 3 \\
\hline 3. Comparability of Subjects for All Observational Studies & 22 \\
\hline - Specific inclusion/exclusion criteria for all groups & 5 \\
\hline - Criteria applied equally to all groups & 3 \\
\hline - Comparability of groups at baseline with regard to disease status and prognostic factors & 3 \\
\hline - Study groups comparable to non-participants with regard to confounding factors & 3 \\
\hline - Use of concurrent controls & 5 \\
\hline - Comparability of follow-up among groups at each assessment & 3 \\
\hline 4. Exposure or Intervention & 11 \\
\hline - Clear definition of exposure & 5 \\
\hline - Measurement method standard, valid and reliable & 3 \\
\hline - Exposure measured equally in all study groups & 3 \\
\hline 5. Outcome measures & 20 \\
\hline - Primary/secondary outcomes clearly defined & 5 \\
\hline - Outcomes assessed blind to exposure or intervention & 5 \\
\hline - Method of outcome assessment standard, valid and reliable & 5 \\
\hline - Length of follow-up adequate for question & 5 \\
\hline 6. Statistical Analysis & 19 \\
\hline - Statistical tests appropriate & 5 \\
\hline - Multiple comparisons taken into consideration & 3 \\
\hline - Modeling and multivariate techniques appropriate & 2 \\
\hline - Power calculation provided & 2 \\
\hline - Assessment of confounding & 5 \\
\hline - Dose-response assessment if appropriate & 2 \\
\hline 7. Results & 8 \\
\hline - Measure of effect for outcomes and appropriate measure of precision & 5 \\
\hline - Adequacy of follow-up for each study group & 3 \\
\hline 8. Discussion & 5 \\
\hline - Conclusions supported by results with possible biases and limitations taken into conside & \\
\hline 9. Funding or Sponsorship & 5 \\
\hline - Type and sources of support for study & \\
\hline TOTAL SCORE & 100 \\
\hline
\end{tabular}

Adapted and modified from West S et al. Systems to Rate the Strength of Scientific Evidence, Evidence Report, Technology Assessment No. 47. AHRQ Publication No. 02-E016 (31). 


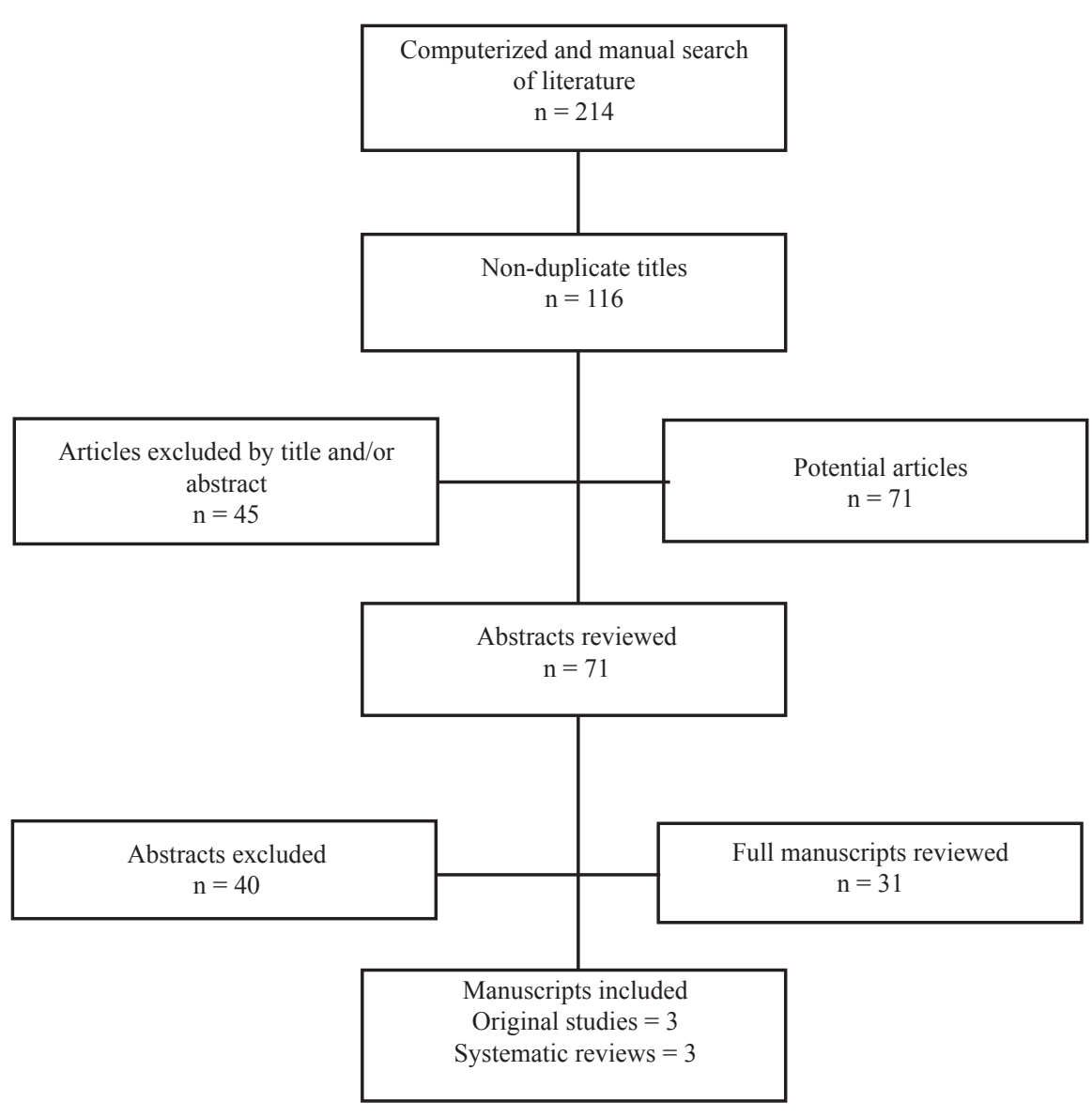

Fig. 1. Literature search flow diagram for diagnostic studies.

\section{Results}

\section{Diagnostic Studies}

\section{Literature Search}

Our extensive search yielded 71 articles for review on thoracic facet joint pain (Fig. 1). However, 3 studies (8-10) and 3 systematic reviews (11-13) of thoracic pain diagnosis met inclusion criteria. All other manuscripts described pain patterns, nerve supply, and therapeutic interventions.

\section{Methodologic Quality Assessment}

A total of 3 studies met the inclusion criteria for methodological assessment. These are illustrated in
Table 6. All 3 studies met inclusion criteria and scored above 50 with scores of 60 to 70 . Of the 3,2 were prospective studies $(8,9)$ and one was a retrospective evaluation (10).

\section{Descriptive Characteristics}

Descriptive characteristics of these studies is included in Table 7. All 3 studies were performed by the same group, with utilization of the same methodology, with controlled comparative local anesthetic blocks with $75 \%$ or $80 \%$ pain relief based on the duration of local anesthetics with lidocaine administered first, followed by bupivacaine, and with ability to perform maneuvers which were painful prior to injection therapy, and also the duration of the relief with 
the second block exceeding the first block irrespective of the duration in hours, days, or months. These studies evaluated not only the prevalence but also falsepositive rate with confidence intervals. There was no significant difference among the 3 studies with prevalence or false positive rate. The selection criteria, inclusion, and exclusion criteria of the patients was the same in all 3 studies.

\section{Diagnostic Accuracy}

The accuracy was established in 3 studies based on a false-positive rate of $42 \%$ to $58 \%$. Confidence intervals $(95 \% \mathrm{Cl})$ ranged from $26 \%$ to $78 \%$. Results of a combination of 3 studies showed prevalence of $40 \%$ ( $95 \% \mathrm{Cl}$ of $33 \%$ to $48 \%$ ) with dual blocks and a falsepositive rate of $42 \%(95 \% \mathrm{Cl}$ of $33 \%$ to $51 \%)$ with a single block.

\section{Prevalence}

The prevalence was illustrated to be $34 \%$ to $48 \%$. Confidence intervals $(95 \% \mathrm{Cl})$ ranged from $22 \%$ to $62 \%$ (Table 8). The combination of results of all 3 studies yielded a prevalence rate of $40 \%$ (with a $95 \% \mathrm{Cl}$ of $33 \%$ to $48 \%$ ) and a false-positive rate of $42 \%$ (with a $95 \% \mathrm{Cl}$ of $33 \%$ to $51 \%$ ).

\section{Confounding Factors}

Influence of psychological factors was evaluated in the diagnosis of thoracic facet joint pain in only one study (36). Based on this evaluation (36), the prevalence of facet joint pain in patients suffering with chronic upper or mid back pain involving thoracic facet joints was shown to be present in $40 \%(95 \% \mathrm{Cl}$ $18 \%$ to $62 \%$ ) in patients without psychopathology, whereas it was $31 \%(95 \% \mathrm{Cl} 16 \%$ to $47 \%)$ in patients with vs $37 \%$ ( $95 \% \mathrm{Cl} 19 \%$ to $54 \%$ ) without major depression, $33 \%$ (95\% Cl $19 \%$ to $48 \%$ ) versus $35 \%$ (95\% Cl $15 \%$ to $55 \%$ ) in patients with or without generalized anxiety disorder, and $36 \%$ (95\% Cl $7 \%$ to $65 \%$ ) versus $33 \%(95 \% \mathrm{Cl} 21 \%$ to $46 \%)$ in patients with or without somatization disorder without any significant differences between the patients with psychological disorders and without psychopathology. However, due to small numbers in the study, there was a wide variation in $95 \%$ confidence intervals. This report is not considered conclusive with regards to the influence of psychological factors. Sedation as a confounding factor was evaluated in the cervical and lumbar spine (37-40). However, no such studies were available in the thoracic spine.

Table 6. Methodologic quality assessment and scoring of thoracic diagnostic facet joint nerve block studies.

\begin{tabular}{|c|c|c|c|c|c|c|c|c|}
\hline \multirow[b]{2}{*}{ Study } & \multirow[b]{2}{*}{$\begin{array}{c}1 \\
\text { Study } \\
\text { Population } \\
(\mathbf{3 0})\end{array}$} & \multirow[b]{2}{*}{$\begin{array}{c}2 \\
\text { Adequate } \\
\text { Description } \\
\text { of Test } \\
\text { (15) }\end{array}$} & \multicolumn{2}{|c|}{$\begin{array}{c}3 \\
\text { Appropriate Reference } \\
\text { Standard } \\
(\mathbf{2 0})\end{array}$} & \multicolumn{2}{|c|}{$\begin{array}{c}4 \\
\text { Blinded Comparison of } \\
\text { Test } \\
(20)\end{array}$} & \multirow[b]{2}{*}{$\begin{array}{c}5 \\
\text { Avoidance } \\
\text { of } \\
\text { Verification } \\
\text { Bias } \\
\text { (15) }\end{array}$} & \multirow[b]{2}{*}{$\begin{array}{c}\text { TOTAL } \\
(\mathbf{1 0 0})\end{array}$} \\
\hline & & & $\begin{array}{c}10 \\
\text { Appropriate } \\
\text { reference } \\
\text { standard } \\
\text { (gold } \\
\text { standard) } \\
\text { used for } \\
\text { comparison }\end{array}$ & $\begin{array}{c}10 \\
\text { Reference } \\
\text { standard } \\
\text { reproducible }\end{array}$ & $\begin{array}{c}10 \\
\text { Evaluation } \\
\text { of test } \\
\text { without } \\
\text { knowledge } \\
\text { of disease } \\
\text { status, if } \\
\text { possible }\end{array}$ & $\begin{array}{c}10 \\
\text { Independent, } \\
\text { blind } \\
\text { interpretation } \\
\text { of test and } \\
\text { reference }\end{array}$ & & \\
\hline $\begin{array}{l}\text { Manchikanti et al } \\
2004 \text { (9) }\end{array}$ & 30 & 15 & - & 10 & - & - & 15 & 70 \\
\hline $\begin{array}{l}\text { Manchikanti et al } \\
2002 \text { (8) }\end{array}$ & 30 & 15 & - & 10 & - & - & 15 & 70 \\
\hline $\begin{array}{l}\text { Manchukonda et } \\
\text { al } 2007 \text { (10) }\end{array}$ & 30 & 15 & - & 10 & - & - & 5 & 60 \\
\hline
\end{tabular}

( ) weighted item score

Methodological criteria and scoring adapted from West S et al. Systems to Rate the Strength of Scientific Evidence, Evidence Report, Technology Assessment No. 47. AHRQ Publication No. 02-E016 (31). 
Table 7. Descriptive characteristics of diagnostic thoracic facet joint interventions.

\begin{tabular}{|c|c|c|c|c|c|}
\hline Study/Methods & Participants & Intervention(s) & Outcome(s) & Result(s) & Conclusion(s) \\
\hline $\begin{array}{l}\text { Manchikanti et } \\
\text { al } 2002(8) \\
\text { Prospective }\end{array}$ & $\begin{array}{l}46 \text { consecutive } \\
\text { patients with } \\
\text { chronic midback } \\
\text { and upper back } \\
\text { pain }\end{array}$ & $\begin{array}{l}\text { Diagnostic facet } \\
\text { joint nerve } \\
\text { blocks using } \\
\text { lidocaine } 1 \% \text {, } \\
\text { initially followed } \\
\text { by bupivacaine } \\
0.5 \% \text { on separate } \\
\text { occasions, usually } \\
3 \text { to } 4 \text { weeks apart. }\end{array}$ & $\begin{array}{l}80 \% \text { pain relief } \\
\text { with and ability } \\
\text { to perform } \\
\text { previously painful } \\
\text { movements. } \\
\text { The relief with } \\
\text { bupivacaine to } \\
\text { last longer than } \\
\text { lidocaine. }\end{array}$ & $\begin{array}{l}46 \text { patients underwent single blocks } \\
\text { with lidocaine and } 36 \text { of these } \\
\text { patients, or } 78 \% \text {, were positive for } \\
\text { facet joint pain, reporting a definite } \\
\text { response. } \\
\text { Confirmatory blocks with } \\
\text { bupivacaine were performed in all } \\
\text { patients who were lidocaine-positive, } \\
\text { with } 61 \% \text {, or } 48 \% \text {, of the total sample } \\
\text { of the lidocaine-positive group, } \\
\text { reporting a definite response with } \\
\text { improvement in their pain. }\end{array}$ & $\begin{array}{l}\text { Comparative local } \\
\text { anesthetic blocks } \\
\text { showed the prevalence } \\
\text { of facet joint pain to } \\
\text { be } 48 \% \text {, with single } \\
\text { blocks carrying a } \\
\text { false-positive rate of } \\
58 \% \text {. }\end{array}$ \\
\hline $\begin{array}{l}\text { Manchikanti et } \\
\text { al } 2004 \text { (9) } \\
\text { Prospective }\end{array}$ & $\begin{array}{l}500 \text { consecutive } \\
\text { patients with } \\
\text { chronic, non- } \\
\text { specific spine } \\
\text { pain } \\
72 \text { patients with } \\
\text { thoracic pain } \\
\text { were evaluated. }\end{array}$ & $\begin{array}{l}\text { Controlled } \\
\text { comparative local } \\
\text { anesthetic blocks } \\
\text { ( } 1 \% \text { lidocaine } \\
\text { or } 1 \% \text { lidocaine } \\
\text { followed by } 0.25 \% \\
\text { bupivacaine). }\end{array}$ & $\begin{array}{l}80 \% \text { pain relief } \\
\text { with and ability } \\
\text { to perform } \\
\text { previously painful } \\
\text { movements. } \\
\text { The relief with } \\
\text { bupivacaine to } \\
\text { last longer than } \\
\text { lidocaine. }\end{array}$ & $\begin{array}{l}\text { The prevalence of facet joint pain in } \\
\text { patients with chronic cervical spine } \\
\text { pain was } 55 \% \text { ( } 95 \% \text { CI, } 49 \%-61 \%) \text {, } \\
\text { with thoracic spine pain was } 42 \% \\
\text { ( } 95 \% \text { CI, } 30 \%-53 \%) \text {, and in with } \\
\text { lumbar spine pain was } 31 \% \text { ( } 95 \% \\
\text { CI, } 27 \% \text { - 36\%). The false-positive } \\
\text { rate with single blocks with lidocaine } \\
\text { was } 63 \%(95 \% \text { CI, } 54 \%-72 \%) \text { in the } \\
\text { cervical spine, } 55 \%(95 \% \text { CI, } 39 \% \\
-78 \% \text { ) in the thoracic spine, and } \\
27 \%(95 \% \text { CI, } 22 \%-32 \% \text { ) in the } \\
\text { lumbar spine. }\end{array}$ & $\begin{array}{l}\text { Facet joints are } \\
\text { clinically important } \\
\text { spinal pain generators } \\
\text { in a significant } \\
\text { proportion of patients } \\
\text { with chronic spinal } \\
\text { pain. }\end{array}$ \\
\hline $\begin{array}{l}\text { Manchukonda et } \\
\text { al } 2007 \text { (10) } \\
\text { Retrospective }\end{array}$ & $\begin{array}{l}500 \text { consecutive } \\
\text { patients with } \\
\text { chronic facet or } \\
\text { zygapophysial } \\
\text { joint pain. } \\
65 \text { patients with } \\
\text { thoracic pain } \\
\text { were evaluated. }\end{array}$ & $\begin{array}{l}\text { Diagnostic blocks } \\
\text { using } 0.5 \mathrm{~mL} \text { of } \\
1 \% \text { lidocaine per } \\
\text { nerve. Patients } \\
\text { with lidocaine } \\
\text { positive results } \\
\text { were further } \\
\text { studied using } \\
0.5 \mathrm{~mL} \text { of } 0.25 \% \\
\text { bupivacaine } \\
\text { per nerve on a } \\
\text { separate occasion. }\end{array}$ & $\begin{array}{l}80 \% \text { pain relief } \\
\text { with and ability } \\
\text { to perform } \\
\text { previously painful } \\
\text { movements. } \\
\text { The relief with } \\
\text { bupivacaine to } \\
\text { last longer than } \\
\text { lidocaine. }\end{array}$ & $\begin{array}{l}\text { Prevalence of facet joint pain was } \\
39 \% \text { in the cervical spine ( } 95 \% \text { CI, } \\
32 \%-45 \%) ; 34 \% \text { ( } 95 \% \text { CI, } 22 \%-47 \% \text { ) } \\
\text { in the thoracic pain; and } 27 \%(95 \% \\
\text { CI, } 22 \%-33 \% \text { ) in the lumbar spine. } \\
\text { The false-positive rate with a single } \\
\text { block in the cervical region was } 45 \% \text {, } \\
\text { in the thoracic region was } 42 \% \text {, and } \\
\text { in the lumbar region } 45 \% \text {. }\end{array}$ & $\begin{array}{l}\text { Significant prevalence } \\
\text { of facet joint pain in } \\
\text { chronic spinal pain. }\end{array}$ \\
\hline
\end{tabular}

\section{Criterion Standard}

No tissue diagnosis (biopsy or autopsy) techniques are available to diagnose facet joint pain and confirm specificity and sensitivity of diagnostic blocks. However, pain relief and stability of the diagnosis with long-term follow-up are employed as the criterion standards and are accepted across different medical disciplines (41-43). Long-term relief of facet joint interventions has been demonstrated $(27-29,44-48)$.

\section{Study Designs}

Mistakenly, many reviewers have been calling for randomized controlled trials for diagnostic interventions (49-53). However, quality assessment of diagnostic studies should not involve randomized trials. Rather, it involves consecutive or non-consecutive allocation and observational studies $(31,51-53)$. 
Pain Physician: September/October 2008:11:611-629

Table 8. Data of prevalence with controlled diagnostic blocks and false-positive rates in thoracic region.

\begin{tabular}{|l|c|c|c|c|}
\hline \multicolumn{1}{|c|}{ Study } & $\begin{array}{c}\text { Methodological } \\
\text { Quality Scoring } \\
\text { (AHRQ) }\end{array}$ & Participants & Prevalence & False-Positive Rate \\
\hline Manchikanti et al 2002 (8) & 70 & 46 & $48 \%(95 \%$ CI 34\%-62\%) & $58 \%(95 \%$ CI 38\%-78\%) \\
\hline Manchikanti et al 2004 (9) & 70 & 72 & $42 \%(95 \%$ CI 30\%-53\%) & $55 \%(95 \%$ CI 39\%-78\%) \\
\hline Manchukonda et al 2007 (10) & 60 & 65 & $34 \%(95 \%$ CI 22\%-47\%) & $42 \%(95 \%$ CI $26 \%-59 \%)$ \\
\hline Combined Results (Average) & 66.66 & 173 & $40 \%(95 \%$ CI 33\%- $48 \%)$ & $42 \%(95 \%$ CI 33\%-51\%) \\
\hline
\end{tabular}

$\mathrm{AHRQ}=$ Agency for Healthcare Research and Quality; CI = confidence interval

\section{Level of Evidence}

The evidence is Level I or Level II-1 based on the 3 included studies, based on the USPSTF criteria (33).

\section{Recommendations}

Based on Guyatt et al's criteria (34), with Level I or Level II-1 evidence determined by USPSTF criteria, recommendation is $1 \mathrm{~A}$ or $1 \mathrm{~B} /$ strong.

\section{Therapeutic Facet Joint Interventions}

\section{Literature Search}

A literature search was carried out for therapeutic facet joint interventions including thoracic intraarticular facet joint injections, thoracic medial branch blocks, and thoracic radiofrequency neurotomy (Figs. 2 and 3).

\section{Intraarticular Facet Joint Blocks}

While the literature search for thoracic intraarticular facet joint blocks yielded 16 studies, none of them included clinical studies evaluating the outcomes of thoracic intraarticular facet joint injections (Figs. 2 and 3).

\section{Medial Branch Blocks}

Our search strategy for medial branch blocks (Figs. 2 and 3 ) identified 21 total references, of which 2 evaluated the therapeutic role of medial branch blocks and one of them was a randomized trial (54), with the other one being a prospective study (29).

\section{Methodologic Quality Assessment}

Methodologic quality assessment of the sole randomized trial available is illustrated in Table 9 with a total score of 60 . Methodologic criteria and scoring was adapted from Koes et al (35) utilized for efficacy of epidural steroid injections for low back pain and sciatica in a systematic review of randomized controlled trials.

Methodologic quality assessment of the sole observational study available is illustrated in Table 10 with a total score of 69. Methodologic criteria and scoring was adapted and modified from AHRQ (31).

\section{Study Characteristics}

Manchikanti et al (54) reported preliminary results of the effectiveness of thoracic medial branch blocks in managing chronic pain, in a randomized, double-blind controlled trial, illustrating the results of 48 patients with 24 patients in each group receiving either local anesthetic or steroid. The inclusion criteria were diagnosis of thoracic facet joint pain by means of comparative, controlled diagnostic blocks. The outcome measures included numeric pain scores, Oswestry Disability Index (ODI), opioid intake, and return to work status with assessment of all outcomes at baseline, 3, 6, and 12 months. The results showed the majority of the patients with significant improvement in pain relief ( $>50 \%$ ) and functional status improvement. Patients receiving only local anesthetic in Group I showed significant pain relief and functional improvement of $79 \%$ at 3, 6, and 12 months. In Group II, patients receiving bupivacaine with steroids for medial branch blocks showed improvement of $83 \%, 81 \%$, and $79 \%$ at 3, 6, and 12 months. Based on the results of this study, it appears that patients may experience significant pain relief of 46 to 50 weeks of a year, requiring approximately 3 to 4 treatments with an average relief of 16 weeks per episode of treatment.

The advantages of this study include a randomized, double-blind, pragmatic design in a non-aca- 


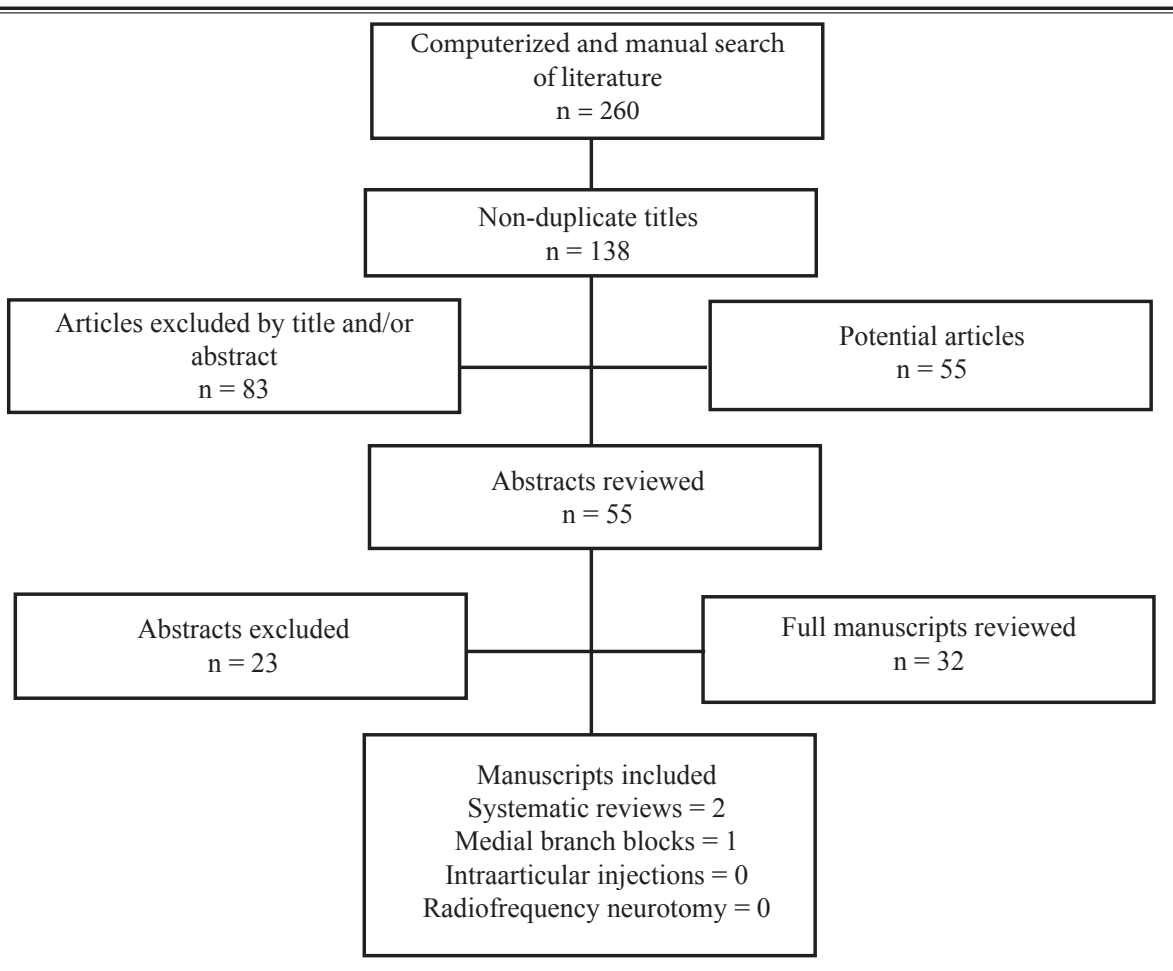

Fig. 2. The flow diagram illustrating randomized trials evaluating thoracic facet joint interventions.

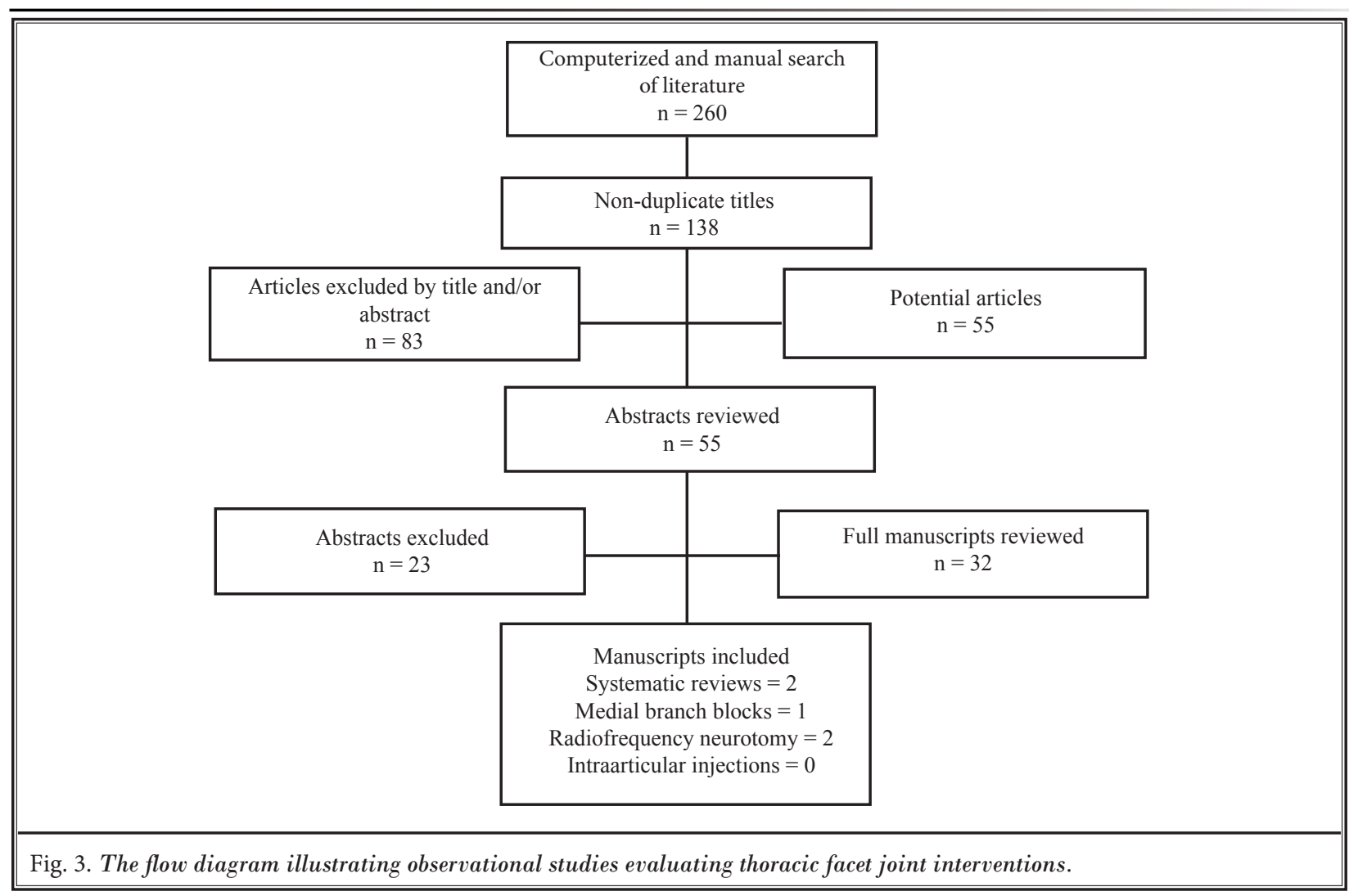


Table 9. Methodological assessment of randomized clinical trials of thoracic facet joint interventions.

\begin{tabular}{|c|c|c|c|}
\hline & CRITERION & $\begin{array}{l}\text { WEIGHTED } \\
\text { SCORE }\end{array}$ & Manchikanti et al (54) \\
\hline & opulation & & \\
\hline A & Homogeneity & 2 & 2 \\
\hline B & Comparability of relevant baseline characteristics & 5 & 2 \\
\hline $\mathrm{C}$ & Randomization procedure adequate & 4 & 4 \\
\hline $\mathrm{D}$ & Drop-outs described for each study group separately & 3 & 3 \\
\hline $\mathrm{E}$ & $<20 \%$ loss for follow-up & 2 & 2 \\
\hline & $<10 \%$ loss for follow-up & 2 & 2 \\
\hline $\mathrm{F}$ & $>50$ subject in the smallest group & 8 & - \\
\hline & $>100$ subjects in the smallest group & 9 & - \\
\hline & ntions & & \\
\hline G & Interventions included in protocol and described & 10 & 10 \\
\hline $\mathrm{H}$ & Pragmatic study & 5 & 5 \\
\hline I & Co-interventions avoided & 5 & - \\
\hline $\mathrm{J}$ & Placebo-controlled & 5 & - \\
\hline Ef & & & \\
\hline K & Patients blinded & 5 & 5 \\
\hline $\mathrm{L}$ & Outcome measures relevant & 10 & 10 \\
\hline M & Blinded outcome assessments & 10 & - \\
\hline $\mathrm{N}$ & Follow-up period adequate & 5 & 5 \\
\hline & esentation and analysis & & \\
\hline $\mathrm{O}$ & Intention-to-treat analysis & 5 & 5 \\
\hline $\mathrm{P}$ & Frequencies of most important outcomes presented for each treatment group & 5 & 5 \\
\hline & SCORE & 100 & 60 \\
\hline
\end{tabular}

Methodological criteria and scoring adapted from Koes BW et al. Efficacy of epidural steroid injections for low-back pain and sciatica: A systematic review of randomized clinical trials. Pain 1995; 63:279-288 (35).

demic setting with appropriate and relevant outcome measures provided at various treatment points. The disadvantages include the small number of patients, lack of placebo control, and a single center study.

The observational study by Manchikanti et al (29) examined the therapeutic benefit of thoracic medial branch blocks in a prospective outcome study. In 55 consecutive patients with thoracic facet pain confirmed by comparative diagnostic facet nerve blocks, more than two-thirds of patients obtained significant pain relief (> 50\%) with bupivacaine and methylprednisolone compared to baseline measurements, (71\% of the patients at 3 months and 6 months, $76 \%$ of the patients at 12 months, $71 \%$ at 24 months, and $69 \%$ at 36 months). Patients received approximately 3 to 4 blocks per year with an average duration of relief per treatment of about 4 months.

The disadvantage of this study included a small number of patients, even in a prospective evaluation, and lack of randomization and a comparative group. However, the advantages include a significant number of patients $(n=55)$ with a long-term monitoring of 36 months, in a design which is practical and pragmatic.

Table 11 describes study characteristics. 
Table 10. AHRQ quality assessment criteria for observational studies of facet joint interventions.

\begin{tabular}{|c|c|c|}
\hline CRITERION & $\begin{array}{l}\text { Weighted } \\
\text { Score }\end{array}$ & $\begin{array}{l}\text { Manchikanti et } \\
\text { al (29) }\end{array}$ \\
\hline Study Question & 2 & \\
\hline Clearly focused and appropriate question & 2 & 2 \\
\hline Study Population & 8 & \\
\hline Description of study population & 5 & 5 \\
\hline Sample size justification & 3 & - \\
\hline 3. Comparability of Subjects for All Observational Studies & 22 & \\
\hline - $\quad$ Specific inclusion/exclusion criteria for all groups & 5 & 5 \\
\hline Criteria applied equally to all groups & 3 & 3 \\
\hline Comparability of groups at baseline with regard to disease status and prognostic factors & 3 & - \\
\hline Study groups comparable to non-participants with regard to confounding factors & 3 & - \\
\hline Use of concurrent controls & 5 & - \\
\hline Comparability of follow-up among groups at each assessment & 3 & 3 \\
\hline Exposure or Intervention & 11 & \\
\hline Clear definition of exposure & 5 & 5 \\
\hline Measurement method standard, valid and reliable & 3 & 3 \\
\hline Exposure measured equally in all study groups & 3 & - \\
\hline Outcome measures & 20 & \\
\hline Primary/secondary outcomes clearly defined & 5 & 5 \\
\hline Outcomes assessed blind to exposure or intervention & 5 & - \\
\hline Method of outcome assessment standard, valid and reliable & 5 & 5 \\
\hline Length of follow-up adequate for question & 5 & 5 \\
\hline Statistical Analysis & 19 & \\
\hline Statistical tests appropriate & 5 & 5 \\
\hline Multiple comparisons taken into consideration & 3 & 3 \\
\hline Modeling and multivariate techniques appropriate & 2 & - \\
\hline Power calculation provided & 2 & - \\
\hline Assessment of confounding & 5 & 5 \\
\hline Dose-response assessment if appropriate & 2 & - \\
\hline Results & 8 & \\
\hline Measure of effect for outcomes and appropriate measure of precision & 5 & 5 \\
\hline Adequacy of follow-up for each study group & 3 & - \\
\hline Discussion & 5 & \\
\hline $\begin{array}{l}\text { Conclusions supported by results with possible biases and limitations taken into } \\
\text { consideration }\end{array}$ & 5 & 5 \\
\hline Funding or Sponsorship & 5 & \\
\hline - $\quad$ Type and sources of support for study & 5 & 5 \\
\hline TOTAL SCORE $=100$ & 100 & 69 \\
\hline
\end{tabular}

Adapted and modified from West S et al. Systems to Rate the Strength of Scientific Evidence, Evidence Report, Technology Assessment No. 47. AHRQ Publication No. 02-E016 (31). 
Table 11. Study characteristics of published reports of thoracic medial branch blocks.

\begin{tabular}{|c|c|c|c|c|c|}
\hline Study/Methods & Participants & Intervention(s) & Outcome(s) & Result(s) & $\begin{array}{c}\text { Conclusion(s) } \\
\text { Short-term relief } \leq 6 \mathrm{mos} \\
\text { Long-term relief }>6 \mathrm{mos}\end{array}$ \\
\hline $\begin{array}{l}\text { Manchikanti et } \\
\text { al (29) } \\
\text { Prospective } \\
\text { outcome study }\end{array}$ & $\begin{array}{l}55 \\
\text { consecutive } \\
\text { patients, } \\
\text { all meeting } \\
\text { diagnostic } \\
\text { criteria for } \\
\text { thoracic facet } \\
\text { joint pain }\end{array}$ & $\begin{array}{l}\text { Thoracic facet joint } \\
\text { nerve blocks performed } \\
\text { using bupivacaine with } \\
\text { or without Sarapin and } \\
\text { depomethylprednisolone. }\end{array}$ & $\begin{array}{l}\text { Measured numeric } \\
\text { pain scores, } \\
\text { Oswestry Disability } \\
\text { Index, employment } \\
\text { status, and Pain } \\
\text { Patient Profile at } \\
3,6,12,24 \text {, and } 36 \\
\text { mos. }\end{array}$ & $\begin{array}{l}\text { Significant }(\geq 50 \%) \text {, was } \\
\text { observed in } 71 \% \text { of the } \\
\text { patients at } 3 \text { mos and } 6 \text { mos, } \\
76 \% \text { at } 12 \text { mos, } 71 \% \text { at } 24 \\
\text { mos, and } 69 \% \text { at } 36 \text { mos. }\end{array}$ & $\begin{array}{l}\text { Therapeutic thoracic } \\
\text { medial branch blocks } \\
\text { were an effective } \\
\text { modality of treatment } \\
\text { in managing chronic } \\
\text { thoracic pain secondary } \\
\text { to facet joint involvement } \\
\text { confirmed by controlled, } \\
\text { comparative local } \\
\text { anesthetic blocks. } \\
\\
\text { Positive short-term and } \\
\text { long-term relief. }\end{array}$ \\
\hline $\begin{array}{l}\text { Manchikanti et } \\
\text { al (54) } \\
\text { Randomized, } \\
\text { double-blind, } \\
\text { controlled trial }\end{array}$ & $\begin{array}{l}48 \text { patients } \\
\text { were } \\
\text { included, } \\
\text { with } 24 \\
\text { patients } \\
\text { in each of } \\
\text { the local } \\
\text { anesthetic } \\
\text { and steroid } \\
\text { groups }\end{array}$ & $\begin{array}{l}\text { Group I patients } \\
\text { received thoracic medial } \\
\text { branch blocks with } \\
\text { bupivacaine, whereas } \\
\text { Group II patients } \\
\text { received thoracic } \\
\text { medial branch blocks } \\
\text { with bupivacaine } \\
\text { and non-particulate } \\
\text { betamethasone }\end{array}$ & $\begin{array}{l}\text { Numeric pain } \\
\text { scores (NRS), } \\
\text { Oswestry Disability } \\
\text { Index (ODI), } \\
\text { opioid intake, } \\
\text { and return to } \\
\text { work status. } \\
\text { All outcomes } \\
\text { were assessed } \\
\text { at baseline, } 3 \\
\text { months, } 6 \text { months, } \\
\text { and } 12 \text { months. } \\
\text { Significant pain } \\
\text { relief was defined } \\
\text { as > 50\% pain } \\
\text { relief. Significant } \\
\text { functional } \\
\text { improvement was } \\
\text { defined as } 40 \% \\
\text { reduction of ODI. }\end{array}$ & $\begin{array}{l}\text { In Group I, 79\% of patients } \\
\text { showed significant pain relief } \\
\text { and functional improvement } \\
\text { at } 3 \text { months, } 6 \text { months, and } \\
12 \text { months, a significant } \\
\text { change from baseline. In } \\
\text { Group II, } 83 \%, 81 \% \text {, and } \\
79 \% \text { of patients showed } \\
\text { significant pain relief and } \\
\text { functional improvement at } \\
3 \text { months, } 6 \text { months, and } \\
12 \text { months, a significant } \\
\text { change from baseline. The } \\
\text { majority of the patients } \\
\text { experienced significant pain } \\
\text { relief of } 46 \text { to } 50 \text { weeks, } \\
\text { requiring approximately } 3 \text { to } \\
4 \text { treatments with an average } \\
\text { relief of } 16 \text { weeks per episode } \\
\text { of treatment. }\end{array}$ & $\begin{array}{l}\text { The majority of the } \\
\text { patients in both } \\
\text { groups experienced } \\
\text { significant pain relief } \\
\text { and improvement } \\
\text { in functional status. } \\
\text { Therapeutic thoracic } \\
\text { medial branch blocks, } \\
\text { with or without } \\
\text { steroid, may provide a } \\
\text { management option for } \\
\text { chronic function-limiting } \\
\text { mid back or upper back } \\
\text { pain of facet joint origin. } \\
\\
\text { Positive short-term and } \\
\text { long-term relief. }\end{array}$ \\
\hline
\end{tabular}

\section{Results}

Results of the trials of effectiveness of therapeutic thoracic facet joint nerve blocks are illustrated in Table 12 with both the prospective and randomized double trial meeting the criteria for inclusion, with methodological quality scoring above 50 , illustrating positive results.

\section{Level of Evidence}

Based on the quality of evidence developed by AHRQ (31), the level of evidence is Level I or Level II-1.

\section{Recommendation}

Based on Guyatt et al's criteria (34), the recommendation is $1 \mathrm{~A}$ or $1 \mathrm{~B} /$ strong recommendation, high or moderate quality evidence, with benefits clearly outweighing the risks and burdens, or vice versa, with methodologic quality of supporting evidence derived from high quality randomized and appropriate observational studies, with strong recommendation, which can apply to most patients in most circumstances, without reservation.

\section{Radiofrequency Neurotomy}

The literature search revealed 34 studies for radiofrequency neurotomy (Figs. 2 and 3). Of these, 2 studies $(3,30)$ were identified which showed percutaneous facet denervation of medial branches. However, both of them failed to meet inclusion criteria, with low methodologic quality. 
Table 12. Results of trials of effectiveness of therapeutic thoracic facet joint nerve blocks.

\begin{tabular}{|c|c|c|c|c|c|c|c|c|}
\hline \multirow[b]{2}{*}{ Study } & \multirow[b]{2}{*}{$\begin{array}{c}\text { Study } \\
\text { Characteristics }\end{array}$} & \multirow[b]{2}{*}{$\begin{array}{l}\text { Methodological } \\
\text { Quality Scoring }\end{array}$} & \multirow[b]{2}{*}{ Participants } & \multicolumn{3}{|c|}{ Pain Relief } & \multicolumn{2}{|c|}{ Results } \\
\hline & & & & $3 \mathrm{mos}$ & $6 \mathrm{mos}$ & $12 \mathrm{mos}$ & $\begin{array}{c}\text { Short-term } \\
\text { relief } \\
\leq 6 \mathrm{mos}\end{array}$ & $\begin{array}{c}\text { Long-term } \\
\text { relief } \\
>6 \mathrm{mos}\end{array}$ \\
\hline $\begin{array}{l}\text { Manchikanti et } \\
\text { al } 2006 \text { (29) }\end{array}$ & $\mathrm{P}$ & 54 & $\begin{array}{l}55 \text { consecutive } \\
\text { patients, all meeting } \\
\text { diagnostic criteria } \\
\text { for thoracic facet } \\
\text { joint pain. }\end{array}$ & $71 \%$ & $71 \%$ & $76 \%$ & $\mathrm{P}$ & $\mathrm{P}$ \\
\hline $\begin{array}{l}\text { Manchikanti et } \\
\text { al } 2008 \text { (54) }\end{array}$ & RA, DB & 60 & $\begin{array}{l}\text { Group I-no } \\
\text { steroid=24 } \\
\text { Group II-steroid=24 }\end{array}$ & $\begin{array}{c}79 \% \text { vs } \\
83 \%\end{array}$ & $\begin{array}{l}79 \% \text { vs } \\
81 \%\end{array}$ & $\begin{array}{c}79 \% \text { vs } \\
79 \%\end{array}$ & $\mathrm{P}$ & $\mathrm{P}$ \\
\hline
\end{tabular}

$\mathrm{RA}=$ randomized $\mathrm{DB}=$ double blind $\mathrm{P}=$ Prospective $;$ vs=versus $\mathrm{P}=$ positive $; \mathrm{N}=$ negative

\section{Study Characteristics}

Tzaan and Tasker (30) evaluated percutaneous radiofrequency neurotomy in 118 consecutive percutaneous procedures performed on 90 patients in the Toronto Western Hospital published in 2000. They performed these procedures under general and local anesthesia. The inclusion criteria included temporary total pain relief after local anesthetic blockade of the subject facets by an independent radiologist. The patients were monitored from 1 to 33 (mean 5.6) months after neurotomy, with complete elimination of greater than $50 \%$ subjective reduction of pain considered the criteria for success. For the first or only procedure, it was $41 \%$. The authors noted no significant difference in success rates for procedures performed in the cervical, thoracic, or lumbosacral facets, with unilateral versus bilateral denervations, when 2 to 3 as compared with more than 3 facets were denervated, nor for neurotomies done in patients who had previous spinal surgery compared with those who had not.

Stolker et al (3), in a 1993 publication, reported results of percutaneous facet denervation in chronic thoracic spinal pain in 40 patients. Inclusion criteria composed of duration of pain of 12 months which failed to respond to conservative treatment and also diagnosis based on transient positive response to a prognostic blockade of the medial branch of the dorsal ramus of the thoracic spinal nerve. The short and long-term results of percutaneous thoracic facet denervations in 40 patients were with $47 \%$ pain-free, $35 \%$ with more than $50 \%$ pain-relief, and $17.5 \%$ with no relief at 2 months. After a follow-up of 18 to 54 months in 36 cases, $44 \%$ were pain-free, $39 \%$ had more than $50 \%$ pain relief, and in $17 \%$, the results were poor.
The disadvantages of both the studies include retrospective evaluation without a comparative group, lack of diagnosis by controlled blocks, small number of patients, without adequate outcome measures, and statistical analysis.

\section{Discussion}

This systematic review implicated thoracic facet joints as the source of chronic pain in $34 \%$ to $48 \%$ of patients with chronic mid back and upper back pain based on response to controlled diagnostic blocks of these joints (8-10). Based on this systematic review, false-positive rates of single local anesthetic blocks have been shown to range from $42 \%$ to $58 \%$. The combined results of all 3 studies yielded a prevalence rate of $40 \%(95 \% \mathrm{Cl}, 33 \%-48 \%)$ and a false-positive rate of $42 \%(95 \% \mathrm{Cl}, 33 \%-51 \%)$ which may be defined as narrow confidence intervals both for prevalence as well as for false-positive rate.

This systematic review found Level I or Level II-1 evidence for diagnostic accuracy of thoracic facet joint blocks. The recommendation based on Guyatt et al's (34) criteria is $1 \mathrm{~A}$ or $1 \mathrm{~B} /$ strong recommendation.

On the therapeutic front, Level I or II-1 evidence was found only for thoracic medial branch blocks with $1 \mathrm{~A}$ or $1 \mathrm{~B} /$ strong recommendation. However, we are unable to provide a level of evidence or recommendation for thoracic intraarticular injections and radiofrequency neurotomy.

The diagnostic thoracic facet joint blocks have been shown to be valid. The rationale for diagnostic blocks of the facet or zygapophysial joint(s) by blocking the nerve supply with an intraarticular injection of local anesthetic or by the blockade of the medial 
branches of the dorsal rami that innervate the target joint is based on the belief that one must test to determine whether a particular joint is the source of the pain. The rationale for using thoracic facet joint blocks for diagnosis is based on the fact that facet joints are capable of causing pain and they have a nerve supply $(6,7,16-23)$. Neuroanatomic studies have demonstrated free and encapsulated nerve endings in facet joints, as well as nerves containing substance $P$ and calcitonin gene-related peptide $(55,56)$. Further, thoracic facet joints have been shown to be a source of pain in the upper back, mid back, and referred pain in the chest wall $(6,7,19)$. Based on controlled diagnostic blocks of facet joints, thoracic facet joints have been implicated as responsible for pain in $34 \%$ to $48 \%$ of the patients with mid back and upper back pain (8-13).

The diagnosis of facet joint pain by controlled local anesthetic blocks is considered as valid. Controlled diagnostic blocks with 2 local anesthetics with placebo control are the only means of confirming the diagnosis of facet joint pain. The face validity of thoracic medial branch blocks has been established by injecting small volumes of local anesthetic and contrast material onto the target points.

Construct validity of thoracic facet joint blocks is important to eliminate placebo effect as a source of confounding results and to secure true-positive results as with all other medial branch blocks in the spine (8$13,57,58)$. Further, the hypothesis that testing a patient first with lidocaine and subsequently with bupivacaine provides a means of identifying that the placebo responses have been tested and proven $(59,60)$.

Thoracic medial branch blocks or intraarticular injections may be the only means available to diagnose thoracic facet joint pain, as there are no specific markers to diagnose facet joint pain in any region, specifically the thoracic region $(8-13,19)$. Conventional clinical and radiologic techniques are unreliable in diagnosing facet or zygapophysial joint pain and various patterns of referred pain described for facet joints in the spine are similar to other structures, such as discs. Further, most maneuvers of physical examination are difficult to perform in the thoracic spine and such maneuvers are likely to stress several structures simultaneously, thus failing to provide any reasonable diagnostic criteria. The evidence thus far on physical examination and diagnosis has been controversial.

However, the major disadvantage of assessment of diagnostic utility of thoracic facet joint blocks ap- pears to be that all the evidence is derived from one group of authors, even though methodologic quality assessment is high and $95 \%$ confidence intervals are low.

Though the evidence is not available for radiofrequency neurotomy and thoracic intraarticular steroid injections, evidence for medial branch blocks is Level I or Level II-1. Methodologic quality assessment for medial branch blocks is high. Both the randomized and prospective trials $(29,54)$ showed positive short-term and long-term relief. Consequently, a strong recommendation of $1 \mathrm{~A}$ or $1 \mathrm{~B}$ is provided for medial branch blocks based on Guyatt et al's (34) criteria.

The disadvantages of this evidence synthesis for therapeutic facet joint interventions includes positive evidence only for medial branch blocks, whereas no evidence is available for thoracic intraarticular injections and radiofrequency neurotomy. Further, disadvantages include that both medial branch blocks studies $(29,54)$, which were prospective and randomized, are from one group of authors with lack of replication of results by others.

A systematic review is defined as, "the application of scientific strategies that limit bias by the systematic assembly, critical appraisal, and synthesis of all relevant studies on a specific topic" (61-64). It is hoped that this systematic review has provided expertise in the subject matter and review methodology. In this systematic review, we attempted to answer specific narrow clinical questions - the diagnostic accuracy and validity of facet joint blocks and the level of evidence with recommendation for therapeutic facet joint interventions. A systematic searching, selecting, appraising, interpreting, and summarizing of data from original studies was performed (63-67). The original studies included not only randomized trials for clinical effectiveness, but also observational studies (68-73). As recommended for diagnostic purposes, non-randomized trials were evaluated (51-53). In this review we have also searched for other types of integrative evidence including other systematic reviews and cost effectiveness studies.

This systematic review acknowledges that types of evidence obtained from studies other than randomized controlled trials are important. Essentially, including observational and randomized trials, this systematic review has focused on practical and pragmatic aspects. The results of this systematic review can be applied to patients in practice settings and benefits outweigh the risks and costs. We have also utilized the 
quality of evidence criteria described by AHRQ (Table 2) (31) and recommendations by Guyatt et al (34) (Table 3) rather than the outdated Agency for Health care Policy and Research (AHCPR) criteria generally utilized by systematic reviewers with inclusion of only randomized trials. In this evaluation, we attempted to meet all the criteria described by Lohr (74) evaluating the systems to grade the quality of systematic reviews, which included study question, search strategy, inclusion/exclusion criteria, data extraction, study quality, data synthesis/analysis, and funding aspects.

\section{Conclusion}

Diagnostic thoracic facet joint nerve blocks are safe, valid, and reliable. Based on the review of available studies that met inclusion criteria, the strength of evidence for diagnostic facet joint techniques is Level I or II-1 with a strong recommendation of $1 \mathrm{~A}$ or $1 \mathrm{~B}$.

Based on the review of the included therapeutic studies described herein, no evidence synthesis is available for thoracic intraarticular facet joint injections or thoracic radiofrequency neurotomy. The evidence for medial branch blocks is Level I or II-1 with a strong recommendation of $1 \mathrm{~A}$ or $1 \mathrm{~B}$.

\section{Acknowledgments}

The authors wish to thank the editorial board of Pain Physician, for review and criticism in improving the manuscript and Tonie M. Hatton and Diane E. Neihoff, transcriptionists, for their assistance in preparation of this manuscript.

\section{References}

1. Manchikanti L, Schultz DM, Falco FJ, Singh V. Thoracic facet joint interventions. In Manchikanti L, Singh V (eds). Interventional Techniques in Chronic Spinal Pain, ASIPP Publishing, Paducah, KY, 2007; 277-294.

2. Manchikanti L, Pampati VS. Research designs in interventional pain management: Is randomization superior, desirable or essential? Pain Physician 2002; 5:275-284.

3. Stolker RJ, Vervest AC, Groen GJ. Percutaneous facet denervation in chronic thoracic spinal pain. Acta Neurochir 1993; 122:82-90.

4. Linton SJ, Hellsing AL, Hallden K. A population based study of spinal pain among 35-45-year-old individuals. Spine 1998; 23:1457-1463.

5. Wilson PR. Thoracic facet joint syndrome - a clinical entity? Pain Suppl 1987; 4:S87.

6. Dreyfuss P, Tibiletti C, Dreyer SJ. Thoracic zygapophyseal joint pain patterns: A study in normal volunteers. Spine 1994; 19:807-811.

7. Fukui S, Ohseto K, Shiotani M. Patterns of pain induced by distending the thoracic zygapophyseal joints. Reg Anesth 1997; 22:332-336

8. Manchikanti L, Singh V, Pampati VS, Beyer CD, Damron KS. Evaluation of the prevalence of facet joint pain in chron- ic thoracic pain. Pain Physician 2002; 5:354-359.

9. Manchikanti L, Boswell MV, Singh V, Pampati VS, Damron KS, Beyer CD. Prevalence of facet joint pain in chronic spinal pain of cervical, thoracic, and lumbar regions. BMC Musculoskelet Disord 2004; 5:15.

10. Manchukonda R, Manchikanti KN, Cash KA, Pampati V, Manchikanti L. Facet joint pain in chronic spinal pain: An evaluation of prevalence and false-positive rate of diagnostic blocks. I Spinal Disord Tech 2007; 20:539-545.

11. Seghal N, Dunbar EE, Shah RV, Colson JD. Systematic review of diagnostic utility of facet (zygapophysial) joint injections in chronic spinal pain: An update. Pain Physician 2007; 10:213-228.

12. Boswell MV, Singh V, Staats PS, Hirsch JA. Accuracy of precision diagnostic blocks in the diagnosis of chronic spinal pain of facet or zygapophysial joint origin. Pain Physician 2003; 6:449-456.

13. Sehgal N, Shah RV, McKenzie-Brown $A$, Everett CR. Diagnostic utility of facet (zygapophysial) joint injections in chronic spinal pain: A systematic review of evidence. Pain Physician 2005; 8:211-224.

14. Merskey H, Bogduk N. Thoracic zyg apophysial joint pain. In Classification of Chronic Pain. Descriptions of Chronic Pain Syndromes and Definition of Pain
Terms, 2nd ed. International Association for the Study of Pain. IASP Press, Seattle, 1994, pp 116-117.

15. Bogduk N. Low back pain. Clinical Anatomy of Lumbar Spine and Sacrum, 4th edition. Churchill Livingstone, New York, 2005, pp 183-216.

16. Stolker RJ, Vervest AC, Groen GJ. Parameters in electrode positioning in thoracic percutaneous facet denervation: An anatomical study. Acta Neurochir 1994; 128:32-39.

17. Stolker RJ, Vervest AC, Groen GJ. The treatment of chronic thoracic segmental pain by radiofrequency percutaneous partial rhizotomy. I Neurosurg 1994; 80:986-992.

18. Stolker RJ, Vervest AC, Ramos LM, Groen $\mathrm{GJ}$. Electrode positioning in thoracic percutaneous partial rhizotomy: An anatomical study. Pain 1994; 57:241-251.

19. Dreyfuss P, Tibiletti C, Dreyer S. Sobel J. Thoracic zygapophyseal pain: A review and description of an intraarticular block technique. Pain Digest 1994; 4:44-52.

20. Chua WH, Bogduk N. The surgical anatomy of thoracic facet denervation. Acta Neurochir 1995; 136:140-144.

21. Stolker RJ, Vervest AC, Groen GJ, De Ruiter JW, Hansen L. On the innervation of the dorsal compartment of the thoracic spine. In Stolker RJ, Vervest AC (eds). 
Pain Management by Radiofrequency Procedures in the Cervical and Thoracic Spine: A Clinical and Anatomical Study. Utrecht, Thesis, 1994, pp 133-144.

22. Stilwell DL. The nerve supply of the vertebral column and its associated structures in the monkey. Anat Rec 1956; 125:139-169.

23. Bogduk N. International Spinal Injection Society guidelines for the performance of spinal injection procedures. Part 1: Zygapophyseal joint blocks. Clin J Pain 1997; 13:285-302.

24. Bland JH. Diagnosis of thoracic pain syndromes. In Giles LGF, Singer KP (eds). Clinical Anatomy and Management of Thoracic Spine Pain, Vol. 2. Butterworth-Heinemann, Oxford, 2000, pp 145-156.

25. McInerney J, Ball PA. The pathophysiology of thoracic disc disease. Neurosurg Focus 2000; 9:e1.

26. Boswell MV, Trescot AM, Datta S, Schultz DM, Hansen HC, Abdi S, Sehgal N, Shah RV, Singh V, Benyamin RM, Patel VB, Buenaventura RM, Colson JD, Cordner HJ, Epter RS, Jasper JF, Dunbar EE, Atluri SL, Bowman RC, Deer TR, Hansen HC, Staats PS, Smith HS, Burton AW, Kloth DS, Giordano J, Manchikanti L. Interventional techniques: Evidencebased practice guidelines in the management of chronic spinal pain. Pain Physician 2007; 10:7-111.

27. Boswell MV, Colson JD, Sehgal N, Dunbar EE, Epter R. A systematic review of therapeutic facet joint interventions in chronic spinal pain. Pain Physician 2007; 10:229-254.

28. Manchikanti L, Singh V, Vilims BD, Hansen HC, Schultz DM, Kloth DS. Medial branch neurotomy in management of chronic spinal pain: Systematic review of the evidence. Pain Physician 2002; 5:405-418.

29. Manchikanti L, Manchikanti KN, Manchukonda R, Pampati V, Cash KA. Evaluation of therapeutic thoracic medial branch block effectiveness in chronic thoracic pain: A prospective outcome study with minimum 1-year follow up. Pain Physician 2006; 9:97-105.

30. Tzaan W, Tasker R. Percutaneous radiofrequency facet rhizotomy-experience with 118 procedures and reappraisal of its value. Can J Neurol Sci 2000; 27:125-130.

31. West S, King V, Carey TS, Lohr KN, McK- oy N, Sutton SF, Lux L. Systems to Rate the Strength of Scientific Evidence, Evidence Report, Technology Assessment No. 47. AHRQ Publication No. 02E016. Rockville, MD: Agency for Healthcare Research and Quality, 2002. www. thecre.com/pdf/ahrq-system-strength. pdf

32. Manchikanti L, Singh V, Derby R, Schultz DM, Benyamin RM, Prager JP, Hirsch JA. Reassessment of evidence synthesis of occupational medicine practice guidelines for interventional pain management. Pain Physician 2008; 11:393-482.

33. Berg AO, Allan JD. Introducing the third U.S. Preventive Services Task Force. Am J Prev Med 2001; 20:21-35.

34. Guyatt $\mathrm{G}$, Gutterman D, Baumann MH, Addrizzo-Harris D, Hylek EM, Phillips B, Raskob G, Lewis SZ, Schünemann H. Grading strength of recommendations and quality of evidence in clinical guidelines. Report from an American College of Chest Physicians Task Force. Chest 2006; 129:174-181.

35. Koes BW, Scholten RJ, Mens JM, Bouter LM. Efficacy of epidural steroid injections for low-back pain and sciatica: A systematic review of randomized clinical trials. Pain 1995; 63:279-288.

36. Manchikanti L, Cash KA, Pampati V, Fellows B. Influence of psychological variables on the diagnosis of facet joint involvement in chronic spinal pain. Pain Physician 2008; 11:145-160.

37. Manchikanti L, Pampati V, Damron KS, McManus CD, Jackson SD, Barnhill RC, Martin JC. The effect of sedation on diagnostic validity of facet joint nerve blocks: An evaluation to assess similarities in population with involvement in cervical and lumbar regions. Pain Physician 2006; 9:47-52.

38. Manchikanti L, Damron KS, Rivera J, McManus CD, Jackson SD, Barnhill RC, Martin JC. Evaluation of effect of sedation as a confounding factor in the diagnostic validity of lumbar facet joint pain: A prospective, randomized, double-blind, placebo-controlled evaluation. Pain Physician 2004; 7:411-417.

39. Manchikanti L, Pampati V, Damron KS. The role of placebo and nocebo effects of perioperative administration of sedatives and opioids in interventional pain management. Pain Physician 2005; 8:349-355.

40. Manchikanti L, Pampati V, Damron KS,
McManus CD, Jackson SD, Barnhill RC, Martin JC. A randomized, prospective, double-blind, placebo-controlled evaluation of the effect of sedation on diagnostic validity of cervical facet joint pain. Pain Physician 2004; 7:301-309.

41. Saal JS. General principles of diagnostic testing as related to painful lumbar spine disorders. Spine 2002; 27:25382545.

42. Manchikanti L, Singh V, Pampati S. Are diagnostic lumbar medial branch blocks valid? Results of 2-year followup. Pain Physician 2003; 5:147-153.

43. Carragee EJ, Lincoln T, Parmar VS, Alamin T. A gold standard evaluation of the "discogenic pain" diagnosis as determined by provocative discography. Spine 2006; 31:2115-2123.

44. Manchikanti LM, Singh V, Falco FJE, Cash KM, Fellows B. Cervical medial branch blocks for chronic cervical facet joint pain: A randomized, double-blind, controlled trial with 1-year follow-up. Spine 2008; 33:1813-1820.

45. Manchikanti L, Manchikanti KN, Damron KS, Pampati V. Effectiveness of cervical medial branch blocks in chronic neck pain: A prospective outcome study. Pain Physician 2004; 7:195-201.

46. Manchikanti L, Singh V, Falco FJ, Cash KA, Pampati V. Lumbar facet joint nerve blocks in managing chronic facet joint pain: One-year follow-up of a randomized, double-blind controlled trial: Clinical Trial NCTo0355914. Pain Physician 2008; 11:121-132.

47. Lord SM, Barnsley L, Wallis BJ, McDonald GJ, Bogduk N. Percutaneous radiofrequency neurotomy for chronic cervical zygapophysial joint pain. $N$ Engl J Med 1996; 335:1721-1726.

48. Barnsley L. Percutaneous radiofrequency neurotomy for chronic neck pain: Outcomes in a series of consecutive patients. Pain Med 2005; 6:282286.

49. American College of Occupational and Environmental Medicine (ACOEM) Low Back Disorders. In Occupational Medicine Practice Guidelines: Evaluation and Management of Common Health Problems and Functional Recovery of Workers, Second Edition. OEM Press, Beverly Farms, 2007.

50. American College of Occupational and Environmental Medicine (ACOEM) Chronic Pain. In Occupational Medicine 
Practice Guidelines: Evaluation and Management of Common Health Problems and Functional Recovery of Workers, Second Edition. OEM Press, Beverly Farms; awaiting publication.

51. Reid MC, Lachs MS, Feinstein AR. Use of methodological standards in diag. nostic test research. Getting better but still not good. JAMA 1995; 274:645651.

52. Whiting P, Rutjes A, Reitsma J, Bossuyt P, Kleijnen J. The development of QUADAS: A tool for the quality assessment of studies of diagnostic accuracy included in systematic reviews. $B M C$ Med Res Methodol 2003; 3:25.

53. Bossuyt PM, Reitsma JB, Bruns DE, Gatsonis CA, Glasziou PP, Irwig LM, Lijmer JG, Moher D, Rennie D, de Vet HC; Standards for Reporting of Diagnostic Accuracy. Towards complete and accurate reporting of studies of diagnostic accuracy: The STARD initiative. Clin Chem 2003; 49:1-6.

54. Manchikanti L, Singh V, Falco FJ, Cash KM, Pampati V. Effectiveness of thoracic medial branch blocks in managing chronic pain: A preliminary report of a randomized, double-blind controlled trial: Clinical Trial NCTo0355706. Pain Physician 2008; 11:491-504.

55. McLain RF, Pickar JG. Mechanoreceptor endings in human thoracic and lumbar facet joints. Spine 1998; 23:168-173.

56. Boszczyk BM, Boszczyk AA, Putz R, Buttner A, Benjamin M, Milz S. An immunohistochemical study of the dorsal capsule of the lumbar and thoracic facet joints. Spine 2001; 26:E338-E343.

57. Barnsley L, Lord S, Bogduk N. Comparative local anesthetic blocks in the diagnosis of cervical zygapophysial joints pain. Pain 1993; 55:99-106.
58. Lord SM, Barnsley L, Bogduk N. The utility of comparative local anesthetic blocks versus placebo-controlled blocks for the diagnosis of cervical zygapophysial joint pain. Clin J Pain 1995; 11:208-213.

59. Bonica JJ, Buckley FP. Regional analgesia with local anesthetics. In Bonica JJ (ed). The Management of Pain. Lea \& Febiger, Philadelphia, 1990, pp 1883 1966.

60. Boas RA. Nerve blocks in the diagnosis of low back pain. Neurosurg Clin N Am 1991; 2:806-816.

61. Wright RW, Brand RA, Dunn W, Spindler KP. How to write a systematic review. Clin Orthop Relat Res 2007; 455:2329.

62. Sackett DL, Straus SE, Richardson WS, Rosenberg W, Haynes RB. EvidenceBased Medicine. 2nd ed. , Churchill Livingstone, Edinburgh UK: 2000.

63. Cook DJ, Sackett DL, Spitzer WO. Methodologic guidelines for systematic reviews of randomized control trials in health care from the Potsdam Consultation on Meta-Analysis. J Clin Epidemiol 1995; 48:167-171.

64. Mulrow C, Langhorne P, Grimshaw J. Integrating heterogeneous pieces of evidence in systematic reviews. Ann Intern Med 1997; 127:989-995.

65. Gotzsche PC. Methodology and overt and hidden bias in reports of 196 double-blind trials of nonsteroidal antiinflammatory drugs in rheumatoid arthritis. Control Clin Trials 1989; 10:31-56.

66. Manchikanti L, Singh V, Derby R, Helm $S$, Trescot AM, Staats PS, Prager JP, Hirsch JA. Review of occupational medicine practice guidelines for interventional pain management and potential implications. Pain Physician 2008; 11:271-289.
67. Manchikanti L, Singh V, Helm S, Trescot AM, Hirsch JA. A critical appraisal of 2007 American College of Occupational and Environmental Medicine (ACOEM) practice guidelines for interventional pain management: An independent review utilizing AGREE, AMA, IOM, and other criteria. Pain Physician 2008; 11:291-310.

68. Manchikanti L. Evidence-based medicine, systematic reviews, and guidelines in interventional pain management: Part 1: Introduction and general considerations. Pain Physician 2008; 11:161-186.

69. Cook DJ, Mulrow CD, Haynes RB. Systematic reviews: Synthesis of best evidence for clinical decisions. Ann Intern Med 1997; 126:376-380.

70. Crowther MA, Cook DJ. Trials and tribulations of systematic reviews and metaanalyses. Hematology Am Soc Hematol Educ Program 2007; 2007:493-497.

71. Benson K, Hartz AJ. A comparison of observational studies and randomized, controlled trials. N Engl J Med 2000; 342:1878-1886.

72. Concato J, Shah N, Horwitz RI. Randomized, controlled trials, observational studies, and the hierarchy of research designs. N Engl J Med 2000; 342:18871892.

73. Stroup DF, Berlin JA, Morton SC, Olkin I, Williamson GD, Rennie D, Moher D, Becker BJ, Sipe TA, Thacker SB. Metaanalysis of observational studies in epidemiology: A proposal for reporting. Meta-analysis of Observational Studies in Epidemiology (MOOSE) group. JAMA 2000; 283:2008-2012.

74. Lohr KN. Rating the evidence of scientific evidence: Relevance for quality improvement programs. Int I Qual Health Care 2004; 16:9-18. 